Article

\title{
Sustainable Rural Governance: How Rural Elections in China Lead to Long-Term Social Stability?
}

\author{
Jinrui Xi and Feng Wen * \\ School of International Studies/Academy of Overseas Chinese Studies, Jinan University, Huangpu Avenue \\ W.601, Guangzhou 510632, China; JinruiXi@my.unt.edu \\ * Correspondence: tweif@jnu.edu.cn
}

Received: 18 October 2019; Accepted: 1 November 2019; Published: 6 November 2019

\begin{abstract}
Government inspections are a typical approach that the Chinese government adopts in executing its policy agenda and propagating its ideological ideals. However, top-down administrative imperatives as such tend to be consuming in resources and less effective in actual governance. They are not necessarily the most sustainable means to ensure efficient governance in the long term. Bottom-up self-governance in rural China, on the other hand, provides the essential mechanism for sustainable governance. In this paper we study one of these bottom-up self-governance approaches in China-rural elections. We propose that, via three distinctive mechanisms, rural elections in China serve as a stabilizer for the entire state and fill the loopholes that top-down government inspections potentially allow. Specifically, we argue that individuals with electoral experiences are less likely to engage in protests, or other forms of collective actions, than those without. This effect holds in that, first, elections improve public goods provision in rural China; second, voters' personal experience in elections changes their perception of the Chinese regime from being authoritarian to being benevolent and caring; third, elections expose the Chinese regime to emerging social dissent in a timely fashion that allows for self-correction. This theoretical prescription receives strong empirical, statistical analysis using the latest Asian Barometer Survey (ABS 2014) dataset.
\end{abstract}

Keywords: rural elections; sustainable governance; social stability

\section{Introduction}

Sustainable rural governance dictates that both the state and the rural residents actively engage in such constructive ways of communications with each other that an equilibrium of power balance is established where both parties seek to further their interests while respecting their boundaries. In China, power balance of this kind is yet to be matured. The Chinese Communist Party (CCP) usually plays a much more proactive and dominant role in rural governance. The CCP is the chief arbiter of justice among established and emerging factions in rural societies, administering state policies that aim to alleviate rural poverty, and resolving social disputes that could potentially impair the organic and functional networks in the grassroots. The regime accomplishes these arduous tasks mostly through top-down government inspections and routine administrative assignments [1,2].

Yet, the few bottom-up initiatives found in rural China, such as democratic elections, have received less attention despite their unique utility to state governance. Rural elections, in particular, deserve scholarly probes of their significant contribution to sustainable social stability in China. Rural elections in China, though unable to meet the strict democratic standards, such as multiple candidates and open political campaigns, serve as a valuable institutional device to hold elected village leaders accountable in handling of village affairs. However nominal and manipulated, these elections serve as a useful deterrent against extreme abuse of power or ostensible violation of justice. Rural elections in China effectively help the CCP steer the Chinese society into sustainable 
stability over an extended period of time, in complement to, not at odds with, the CCP's top-down governing devices such as the inspections.

While the Chinese government's top-down mechanisms, such as government inspections, prove to be effective in sustaining its ruling legitimacy [3], such top-down administrative actions are not sustainable means in the long term to ensure an efficient form of governance. Bottom-up self-governance in rural China, on the other hand, provides the essential mechanisms for sustainable governance. In this paper, we propose that, via three distinctive mechanisms, rural elections in China serve as a stabilizer for the entire Chinese state and fill the loopholes that top-down government inspections potentially overlook.

Specifically, we argue that individuals with electoral experiences are less likely to engage in protests or other forms of collective actions than those without. This effect holds in that, first, elections improve public goods provision in rural China; second, voters' personal experience in elections modifies their perception of the Chinese regime from being more authoritarian to being more benevolent and caring; third, elections expose the Chinese regime to emerging social problems in a timely fashion that allows for self-correction.

The paper proceeds as follows: first, we review the existing scholarly works on the relationship of elections and stability to show their attempt to resolve the current debate. Second, we present my theoretic argument of how rural elections in China might lead to sustainable governance in China. Elections assimilate citizens' dissatisfaction into the institutional framework of elections themselves and, therefore, keep them off the streets. Third, we propose a plausible research design with which my theoretical argument can be empirically tested. Finally, we conclude this paper with the direction of future research.

\section{Literature Review}

The literature is replete with discussions on whether elections are conducive to violence or social stability. One strand of the literature elaborates on the promising effect that democratic elections have on facilitating cooperation and consent [4]. Scholars have reached somewhat a consensus that elections contribute to social stability and alleviate popular dissatisfaction by allowing the system to unleash and then integrate differential social forces [5,6]. Elections provide a way to expose and cope with voters' frustration, as well as the mechanism to better the performance of those elected. Elections not only present citizens political alternatives from which they can select one (or more) to be their leaders, but also make it possible for voters to sanction incompetent and disqualified candidates through the electoral system.

However, democracy is not just about elections. Countries practicing only nominal elections without respect for the core democratic values, such as competitive political parties and electoral integrity, do not qualify for being democracies. To ensure stability, democratic institutions are an indispensable part of the entire democratic enterprise. In his seminal study, Przeworski treats democracy as an equilibrium where different political actors, willing to accept electoral failure and trusting that the winner will not manipulate political power once in office, defer to a particular democratic institution and participate in competitions within a designated institutional framework [7]. In comparison to normative theory and social contract theory, Przeworski regards democratic institutions as a very critical part in the equilibrium equation [7]. They are instrumental in "enforcing compliance" among divergent social forces. Without strong democratic institutions, the self-enforcing mechanism that democratic parties have established during the competing process tends to fall apart.

Furthermore, international conflict management literature also affirms the importance of mature democratic institutions. This part of literature reveals that the maturity of democratic institutions matters for consolidating social factions into an organic body of political activities. Peace-building efforts through elections in post-civil conflict proves incapable of harmonizing post-war social divisions when strong democratic institutions are yet to be developed [8]. Post-civil war states face an immense commitment challenge, as neither the government nor the rebels trust that casting electoral ballots 
will protect their safety and protect their interests after they lay down the guns. Each party fears that the other side may abuse and monopolize power when in office. This literature recommends that states downtrodden by civil wars wait for at least one or two years before conducting elections, allowing capable democratic institutions to take root during this time lag.

Other works also cast doubt on the effect of elections on stability. Democracy has its limits in producing social harmony and constraining civil conflicts. On the one hand, democratic elections are expected to provide sufficient social goods, like political rights and social equality; on the other, they have to generate sufficient economic gains to remain as an effective institution. When countries struggle to meet these two requirements of both economic development and personal liberty at the same time, the fledgling democratic institutions are at risk facing rising social factions and ethnic divides [7]. Facilitating economic growth would inevitably produce social inequality and even political repression while promoting equality would slow down economic development. "Institutions conducive to major economic transformation cannot protect all interests; institutions that protect all interests are not an appropriate framework for major economic transformation." [7] (p. 34).

Democratic institutions are thus handicapped by the dilemma between development and equality. Elections can potentially open up cracks in the political system that further degrade the core fabrics that hold a society together. In his important work of democratization, Synder argues that elections provide nationalists with the opportunities to exploit ethnic differences for political gains [9]. Ethnic distinctions are then transformed into irreconcilable factions as ethnic groups desire to support the political party or candidate from its own group. Similarly, Li reports that democratic elections in Chinese villages have provided peasants with the leverage to battle against local government officials found guilty of mishandling government affairs by uniting with elected village cadres [10]. According to Li, elections do not appear to be conducive to social stability. Peasants are now at a better position to launch collective actions, detrimental to the CCP rule.

We are thus left with an unresolved debate about the effect of elections on social stability. While some maintain that elections introduce social peace by incorporating diverse social forces into the political realm, others argue for the opposite. More importantly, we have seen little discussion on the same topic in authoritarian countries. Though it is understandable that authoritarian states lack democratic practices in the same magnitude and density as those seen in democracies, some authoritarian countries have already, to various degrees, initiated democratic elections. Given the need for more scholarly attention to the difference that elections make in governance, this paper engages this discussion and sheds light on how elections help the CCP maintain social stability in China.

\section{Rural Elections in China}

In reaction to the wide-spread rural unrests, the central Chinese government adopted the Organic Law of Village Committees (OLVC) in 1987 [11] (p. 140). The OLVC required that all village leaders be democratically elected. By 1994, elections had been held in nearly half of the Chinese villages [12]. By 1999 , survey shows that $67.8 \%$ villages had held elections [13]. By the year 2002, almost $94 \%$ villages have held democratic elections, according to the Chinese Household Income Project (CHIP 2002) dataset [13]. Upon promulgating this law, policy makers were divided into the conservatives who were against, and the reformers who were in favor of, village elections [14] (pp. 63-68). The conservatives were mainly concerned about a possible erosion of the CCP's power at the local level, while the proponents of elections argued that rural elections might hold the local government officials accountable, thus making the Chinese government more efficient in its governance. Whether or not elections have served the initial purpose that some of the CCP law makers had intended remains to be empirically tested.

China's rural elections are a unique case when compared to democratic practices in liberal democracies. Huntington maintains that village elections in authoritarian countries at large, by meeting villagers' urge of self-government, bring about social stability [5]. However, such an urge of democratic self-governance is largely absent in rural China, despite some reports that democratic awareness of 
villagers in China is increasing [15] (p. 213). Some local village cadres resisted elections at the beginning when elections were initially instituted because the sacrifice made to participate in rural elections outweighs the gain. Villagers in the mountains often have to walk long distances in order to arrive at the voting booth. Some villages were located in mountainous regions, which made mobilization of villagers for political activities extremely hard. Many villagers did not ask for elections. Most of the standardized elections were actually imposed by the central government upon the villages $[16,17]$. Absent bottom-up desire of representation, top-down and forced elections from above might facilitate social stability. However this causal effect may materialize through a different framework from what Huntington's diagnosis [5].

In a similar vein, Milner suggests that elections integrate voters into the general political system, which implies that this kind of integration benefits the state as a whole by buying popular consent through granting popular participation.

"By the very act of casting his ballot, the citizen of the state is involved in a way that alienated or uninvolved voters are not. The casting of a ballot is an affirmation of the effectiveness of representative government ... ... Casting a ballot is more than a choice between parties. It is the direct involvement of the individual in the political system, in the process of government; and for any state-particularly one in the beginning stages of development-that is a very important achievement". [6] (p. 99)

Though villagers participate in elections, they are not yet organically integrated into the state. Elected village leaders are not registered into the formal state bureaucracy. They essentially remain as villagers. Village leaders do not enjoy benefits like the township level officials [18]. They are not entitled to the "iron rice bowl", a secure, life-tenured position, as are the formal government officials. As a result, village leaders in rural China do not have the opportunity to participate in high-level state decision-making. They, therefore, remain excluded from the state apparatus. It is thus too much a stretch to claim that the local villagers enjoy integration into the state system through elections. Isolation between the system and local villagers remains despite regular elections.

Moreover, absent in rural elections in China are partisanship political campaigns. No party formation is allowed in elections [19]. Elections are conducted in a quasi-bureaucratic fashion, mainly focusing on pragmatic matters rather than competitive political ideologies. Democratic campaigns with competing political ideologies can potentially become a challenge to the CCP rule. Traditional literature on democracy has rarely separated parties and elections, assuming the simultaneous co-presence of both parties and elections. China presents a unique case, however, where elections are held without the involvement of political parties. Though conducted under the supervision of the CCP, rural elections in China do not have political propaganda or indoctrination of communism during these elections. Rather, villagers vote mainly for pragmatic concerns and candidate-centered factors [19].

\section{Theory}

Rural elections in China are an effective measure to keep the Chinese society in sustainable stability for three particular reasons. First, elections serve as an important mechanism for improved public goods provisions. More public goods arriving in the hands of the villagers in China will likely reduce their discontent for the regime or for the officials. Second, party-grassroots relations (dangqun guanxi) improve as a result of changed popular perception of the party. Voters' participation in these elections, despite the lack of authentic democratic competition in its truest sense, still works for the good of the Chinese regime in that voters feel a sense of benevolence from the regime. The opportunity to participate in elections is mostly seen by the Chinese as a provided privilege, not a fundamental political right. Third, elections open up windows through which the high authorities in Beijing detect social conflicts and take appropriate measures to self-correct the pitfalls. 
The authoritarian political hierarchy that defines the Chinese regime has often caused much administrative inefficiency. Leaders in China fill political offices at various levels through appointments, as opposed to elections in democracies. Although the central government can monitor local governments and offer incentives for improving the performance of local magistrates, the cost of maintaining faithful policy implementation is exceedingly higher in China than in the democratic system where officials are held accountable through the electoral system. Authoritarian states find it extremely taxing to keep their massive staff in line with the central mandates.

Moreover, the lack of accountability to the population also makes policy implementation ineffective. Local government officials are tempted to enforce policies deviant from the original intent to benefit personal interests [20]. Alternatively, they tend to delay the implementation of unpopular policies and prioritize policies more favorable to their political careers. As a result, as collective actions in the form of protests and petitions soar, elements for instability are introduced to the society. Therefore, allowing local elections should provide remarkable relief to administrative cumbersomeness and implementation inefficiencies.

Elections increase the transparency of public administration and accountability of office holders. Public benefits are to be distributed with more democracy and impartiality. For example, a number of studies have discovered a positive relationship between elections and public goods provisions in China [21-24].

Instituting democratic elections increases pressure on the village leadership to shun away from corruption. One particular case emerged from our field work that lends evidence to this effect is a village in northwest China, Gansu Province. Upon onset of one of the democratic elections, the village leader, Bai, to his great surprise, learned from a source that a significant faction of villagers discontent with his leadership were mobilizing to uproot his position as village leader for the next three-year term. Alarmed by the attempted political assault, Bai worked hard to mobilize support from his faction in order to win the election. That experience pushes Bai to be more diligent and transparent in his future work. Election in this case provides the villagers with the political power to hold the elected village leaders accountable.

Improved local governance [25] (p. 91), such as increased public goods provision, shall reduce local citizens' dissatisfaction over their current state of life. Despite the interference by the CCP into rural elections, Yao has shown that elections encouraged village committees to be more accountable to their constituents, helped limiting corruption, improving the quality of public services (raising expenditure and public investment while reducing the share of administrative expenses in the village budget) [21]. Yang and Tang proposes that institutional performance, is the main source of institutional trust [26]. Improved institutional performance, therefore, produces more popular trust of the CCP regime and then stabilizes the whole system. Smoother flow of public goods will likely alleviate the grievances of the local residents.

Moreover, by so doing, the target to which responsibility is attributed is shifted from the government to the local citizens themselves. As elected officials take the blame for grassroots dissatisfaction caused by political blunders or mismanagements, the central government secures its political currency among the mass and preserves its power. The fact that the central government initiates village elections puts it in a much more advantageous position in its political bargains with the grassroots. Elections head off complaints that may otherwise be directed against the central government and increases ruling legitimacy for the regime. Villagers who have participated in elections are likely to assume responsibility on their own or blame their elected local leaders, rather than the central government.

Revolutionary literature shows that to who people attribute their dissatisfaction matters for social stability. Specifically, Goodwin outlines that revolt becomes much more likely when the state is to blame for major policy failures [27]. Grassroots villagers are unlikely to discredit a regime's ruling legitimacy so long as blames of policy failures are not directed toward the regime. The same logic applies to protests: allowing rural elections frees the Chinese government from blames of policy failures. Whereas dissatisfied villagers can turn their anguish toward the state in systems where they 
are unable to participate in politics, such as voting in elections, they have much less such incentives had elections been granted.

That individuals who have participated in elections are less likely to protest is also related to their changed perception of the government. As appealing to the electoral ballots begins to replace petitioning or protesting against higher authorities, grassroots peasants see the CCP regime through a more positive lens. As local governance improves with better discipline of the local officials and better delivery of public goods, people's perception of the government will accordingly change toward the positive. Such perception change may likely incur profound societal effects. Landry, Davis and Wang conclude that more competitive local elections, by increasing both voter turnout and that the fairness of elections, may both foster greater government accountability and loyalty to the regime [28].

Positive perception of the government makes people less likely to participate in protests because, once adversaries arrive, be it economic or political, people are less likely to blame the government. Given that peasants have already participated in the process of village politics, they are more likely to blame themselves or the village leader whom they elected for negative policy outcomes, rather than the CCP regime. Our fieldwork in village A in Guangdong shows that the election season is usually the time when villagers bring to public contested issues and intend to elect a village leader who sympathizes with their side of perspective.

Scholars of China's rural elections have observed an increased level of obedience from the peasants to the regime after elections [14,29]. Villagers are more compliant toward state policies if their elected leaders help the state carry out those policies. The CCP gains consent in return from the villagers for its relaxation of local power structure. Benefiting from the elections first-hand discourages peasants from participating in protests or other forms of collective action.

Political psychology helps explain the sources for more positive popular perceptions of the government when elections are in place. In an authoritarian state like China, opening up elections in rural areas are likely to be regarded as a "gift" from the central government, which in return wins ruling legitimacy for the CCP. For instance, Kennedy suggests that the CCP offers political rights to vote as a bargain for social stability [30]. Similarly, Wilking and Zhang also argue that the Chinese government offers political rights to impoverished regions as compensation to their economic dissatisfaction [31]. By taking the initiative to adopt the Organic Law for the Village Committees (OLVC) in 1987, the CCP plays the role of a "giver" of rural elections. The party extends elections to the grassroots as a "gift". The OLVC essentially brands the party as being competent of meeting the needs of its people, including needs of political rights. For the Chinese population characterized with a remarkable level of obedience to its political regime (According to the Chinese General Social Survey (CGSS) 2010, more than 87 percent of the respondents admits that they should obey the Chinese government.), a political gift, such as democratic elections, wins a considerable amount of leverage for the government in its future relationship with the grassroots.

This mechanism of heading off responsibility from the central regime to local elected officials is also evident from the perspective of the average villagers. Li finds that electoral competitiveness significantly impacts the likelihood that villagers appeal to elected cadres when they discover that the local policy distracts from what the central government has originally intended [10]. People in villages with more competitive elections are more likely to appeal to their elected village leaders than the leaders in those no-election villages. In China where no democratic election was previously allowed, sudden presence of elections impresses peasants that the central government is open-minded and caring. Giving local citizens rights to vote enables the Chinese government to propaganda itself as a benevolent regime, generous in gratifying what its citizens desire.

Similarly, offering something to a person before he realizes that he needs it creates a marginal gain of appreciation. This buys for the CCP regime an increased level of obedience after villagers eventually come to understand the importance of that offer. In most cases in China, elections are offered before being really asked for by the rural peasants. According to the same dataset cited above, but of a later updated wave conducted in the year of 2013, nearly as many as 9056 (80 percent) of the 11438 
randomly selected respondents agree with the notion that "democracy means the government lords over the people" [32]. Rather than lay a solid foundation of democratic norms and institutions first, parachuting democratic elections in a "top-down", authoritative manner overwhelms the villagers to the extent that they cannot ask for anything more from the state. Handsome doses of political rights to rural peasants help the central government silence a sizeable portion of dissent among the populace.

The last reason for elections in rural China to facilitate social stability in China is that democratic elections expose local administrative pitfalls to the central authorities, providing the regime with an opportunity for self-correction. As Chen and $\mathrm{Xu}$ argues that the institutional mechanisms able to communicate social dissatisfaction to the authorities gives the latter an opportunity to adjust its governing agenda in order to best accommodate the popular taste [33].

In a study on ruling legitimacy of the $\mathrm{CCP}$, Zhu points out that "the Chinese government does not need a political opposition as an alternative. The Chinese government can self-correct itself and fulfill its duty and obligation" [34] (p. 129). Rural elections give the central government the ability to detect its faults and then look within to improve them. Zhu argues that one of the most prominent challenges that China faces now is the appropriate and balanced redistribution of the massive fiscal asset that China has amassed in economic boom of the past thirty years This critically determines the stability of the Chinese society as well as its future development. However, one of the difficulties during this distribution process is the dissonance of practice between the central and local governments [34]. It has become commonplace for local cadres to divert provision into unnecessary programs or even personal use. Therefore, one of the objectives of village self-governance is to hold the local cadres accountable in local affairs, safeguarding the smooth flow of provision from the central to the local $[29,35]$.

The first step to maintain control over, and ensure stability of, the whole system, especially in a sustainable fashion, is to be able to know and locate where the destabilizing social currents initially arise. Organizational cumbersomeness mentioned earlier may keep the central government from key governing details of the local administration. Going down to the local levels to monitor the local officials to carry out the devised policies can become extremely costly and time-consuming.

Election-induced social voices become the main source of information supply. Rising local complaints and protests encouraged by elections help expose tensions fostered over time due to blunders by the local government and disconnectedness between the elites and society. For example, the fact that local elections give rise to collective complaints gives the central regime a microscope to discern and diagnose social dissatisfactions and then self-correct itself through appropriate means [10]. Similarly, Chang and Hess states that "parochial protests can even serve to alert the party's national leadership of local corruption and official malfeasance, even offering alternative, legitimacy-enhancing channels for public inputs into the political system [36] (p. 1174)". To the extent that local elections magnify local dissatisfactions and make them more visible to the political hierarchy, the central authorities will be more able to discern and pinpoint governing loopholes and then taking according measures [36] (p. 1191).

Moreover, elections provide the villagers with courage and leverage to counteract against the local authorities when the latter fail to correctly implement central government policies, fail to accommodate local popular needs or even abuse their power [10,35]. As opposed to the initial one-way dormant relationship where the government issues regulations and extracts taxes while the peasants either resist or painstakingly bear the burden, allowing elections opens up a limited but more fluid market for the candidates for village leadership and the voters to bargain and exchange, replacing incompetent officers and encouraging participation in collective actions [14].

Elections provide the essential momentum to the local governments to change and adapt. For example, a number of studies have reported that the local government officials were initially in strong opposition to the promulgation of the Organic Law of Villagers' Committees in China [14,29,37]. This opposition hints us about local governance. First, as noted by some previous studies [14,29,37], this opposition denotes that a more democratic environment is unfavorable to officials' private interests. 
Second, the local cadres initially unwelcomed the law because it would grant the villagers more freedom and leverage. The adoption of elections might lead to increased demands of change in the local government $[16,29]$. The local government would have to accommodate popular demands if the peasants were given the rights to choose their own leaders. However, parties as well as the bureaucratic structures under the pre-election system can be conservative and unwilling to change. This well explains why the local cadres were initially resistant to the election law upon its promulgation.

For the CCP, maintaining organizational cohesion and discipline over more than 2500 county-level divisions across four bureaucratic tiers, from the central to the provincial to municipal to county and then to the township level, presents a tremendous challenge to the regime. A uniformed, top-down organizational strategy can become very ineffective, as the original policy intent tends to be either intentionally distorted by the local officials for personal gains or unconsciously watered down as they walk down the bureaucratic hierarchy. As a result, some bottom-up push upon the officials by the peasant voters in elections for bureaucratic impartiality and efficiency meets the objectives of the CCP.

The most recent Asian Barometer Survey (ABS) conducted between 2014 and 2016 on mainland China offers the most convincing evidence for this argument. Among the 4068 randomly selected respondents, the majority of them responded to the survey question "How much do you feel that having elections makes the government pay attention to what the people think?" with "A good deal" or "quite a lot". Thirty-eight percent of the respondents who offer these types of positive answers have in the past participated in elections themselves, further confirming the validity of their responses (Asian Barometer Survey Wave 4. Center for East Asia Democratic Studies, College of Social Sciences, National Taiwan University. http://www.asianbarometer.org.).

With the in-depth theoretical interrogation above, I hypothesized at the individual level that:

Hypothesis 1. Individual villagers in China who have witnessed changed government responses toward as a result of elections are more likely to lend higher level of trust to local governments.

\section{Research Design}

\subsection{Dependent Variable}

To operationalize the key concept fleshed out in the theory section, sustainable stability, we used "popular trust toward local government" as a proxy in that, as rural peasants trust toward the local government increases, so does the ruling legitimacy of the CCP regime. Improved ruling legitimacy also leads to sustained social stability, as civilians are more willing to obey the dictates of the government.

The dependent variable of this analysis was trust of the local government, respondents' trust toward their local government. This variable was measured in ordinal values from 1 to 4,1 implying "not trusting the local government at all" and 4 for "Trusting the local government very much."

\subsection{Independent Variable}

The independent variable of this project was election efficacy, the extent to which elections have caused change of government attitude toward the peasants under its jurisdiction. Individual respondents are asked the question: "To what degree do you think elections have changed government's reactions toward the people". This variable is coded as 1 if the respondent rates elections with no efficacy and 4 if the respondent rates high election efficacy.

\subsection{Control Variables}

Control variables in this analysis mainly took into account respondents' perception of the economic condition of China as a whole, national economy. Their perception of the robustness of national economy might indirectly cloud their trust level of the local government. Positive perception of the national economy can help overcome respondents' disenchantment of the local government, since the booming national economy will eventually funnel economic interests to local residents around the country. 
The remaining control variables are idiosyncratic characteristics of individual respondents, social status, income, education, gender, age, marital status, religion and geo-location. All these are important controls in that, for analyzing survey data for social science research, it is imperative to consider how individuals' emotions and unique social and economic situations come into play of their understanding of the research question. For instance, those who are married are more likely to provide accurate assessment of local government performance than those who are not, in that married couples come into more contacts with the local magistrates, for obtaining a marriage license as a case in point. An additional example would be respondents' social status also affects their trust toward the local government. The logic can go both ways: those with higher social status may trust the local government more, as they command such swaying political and financial resources in their localities that local government officials tend to accommodate the preference of these respondents; or close linkages between these respondents and the local government so expose the corruption practices epidemic in Chinese politics that these respondents actually trust the local government less.

\subsection{Unit of Analysis, Number of Observations and Statistical Models}

The unit of analysis of this study was an individual villager. The number of observations was 1845 for the most elaborate statistical model, 3081 for Model 1 and 2791 for Model 2 (see Table 1). The loss of observations as the models becoming more sophisticated was a result of additional missing observation values for new variables included in the models. We employed the Asian Barometer Survey (ABS 2014) as the source of data for this analysis. We conducted an ordinal logit regression model against the ABS dataset collected in mainland China due to the ordinal structure of the dependent variable.

Table 1. Ordinal logit regression analysis of the effect that election efficacy has upon respondents' trust of the local government.

\begin{tabular}{|c|c|c|c|}
\hline \multicolumn{4}{|c|}{ Dependent Variable: Trust of Local Government (1 the Least and 4 the Most) } \\
\hline & Model 1 & Model 2 & Model 3 \\
\hline Election Efficacy & $\begin{array}{c}1.011^{* * *} \\
-0.06\end{array}$ & $\begin{array}{c}0.924^{* * *} \\
-0.06\end{array}$ & $\begin{array}{c}0.968^{* * *} \\
-0.08\end{array}$ \\
\hline Family Economy & & $\begin{array}{l}0.062 \\
-0.05\end{array}$ & $\begin{array}{l}0.057 \\
-0.07\end{array}$ \\
\hline National economy & & $\begin{array}{c}0.273^{* * *} \\
-0.04\end{array}$ & $\begin{array}{c}0.227^{* * *} \\
-0.05\end{array}$ \\
\hline Social Status & & $\begin{array}{c}0.109^{* * *} \\
-0.02\end{array}$ & $\begin{array}{c}0.111^{* * *} \\
-0.02\end{array}$ \\
\hline Income & & & $\begin{array}{l}-0.019 \\
-0.02\end{array}$ \\
\hline Gender & & & $\begin{array}{c}-0.084 \\
-0.1\end{array}$ \\
\hline Education & & & $\begin{array}{c}0 \\
-0.01\end{array}$ \\
\hline Age & & & $\begin{array}{c}0.003 \\
0\end{array}$ \\
\hline Marital & & & $\begin{array}{c}-0.225 \\
-0.16\end{array}$ \\
\hline Christian & & & $\begin{array}{c}-0.173 \\
-0.29 \\
\end{array}$ \\
\hline Muslim & & & $\begin{array}{l}0.052 \\
-0.99 \\
\end{array}$ \\
\hline Buddhist & & & $\begin{array}{c}-0.252 \\
-0.16\end{array}$ \\
\hline Urban_Rural & & & $\begin{array}{c}0.244^{* * *} \\
-0.09\end{array}$ \\
\hline $\begin{array}{l}N \\
\mathrm{chi}^{2}\end{array}$ & $\begin{array}{c}3081 \\
319\end{array}$ & $\begin{array}{c}2791 \\
402\end{array}$ & $\begin{array}{c}1845 \\
275\end{array}$ \\
\hline
\end{tabular}

Note: Table entries are ordinal logistic regression estimates of how rural elections have impacted their trust of local Chinese government. ${ }^{*} p<0.10,{ }^{* *} p<0.05,{ }^{* * *} p<0.01$ Source: Asian Barometer Survey 2014. Data used by permission. 
The ABS (2014) dataset was the most updated version for mainland China and released at the end of the year 2017 by its host institution, National Taiwan University. For this newest wave of data, the ABS (2014) randomly selected 4000 respondents in mainland China and collected information from them with the standardized ABS international questionnaire. The rich reservoir of questions provided the essential data for this research.

\section{Analysis}

Data analysis using an ordinal logit model reveals the significant impact that election efficacy has upon respondents' trust of their local government. As shown in Table 1, election efficacy has a statistically significant $(p<0.01)$, positive effect on trust of the local government across all three different models, suggesting that as elevated election efficacy will lead to improved popular trust toward local governments. Individuals who have witnessed, or things have caused them to believe so, improved government responses because of the implementation of elections in China are more likely to trust their local government.

Substantively, using computational skills, we ran prediction commands to see how exactly election efficacy affects popular trust toward local governments. Shown in Figure 1, as election efficacy increased from the least efficacy on the left end of the X-axis to the most efficacy on its right end, the likelihood that respondents highly trusted their local governments increased significantly from $1.4 \%$ to $21 \%$, all else equal.

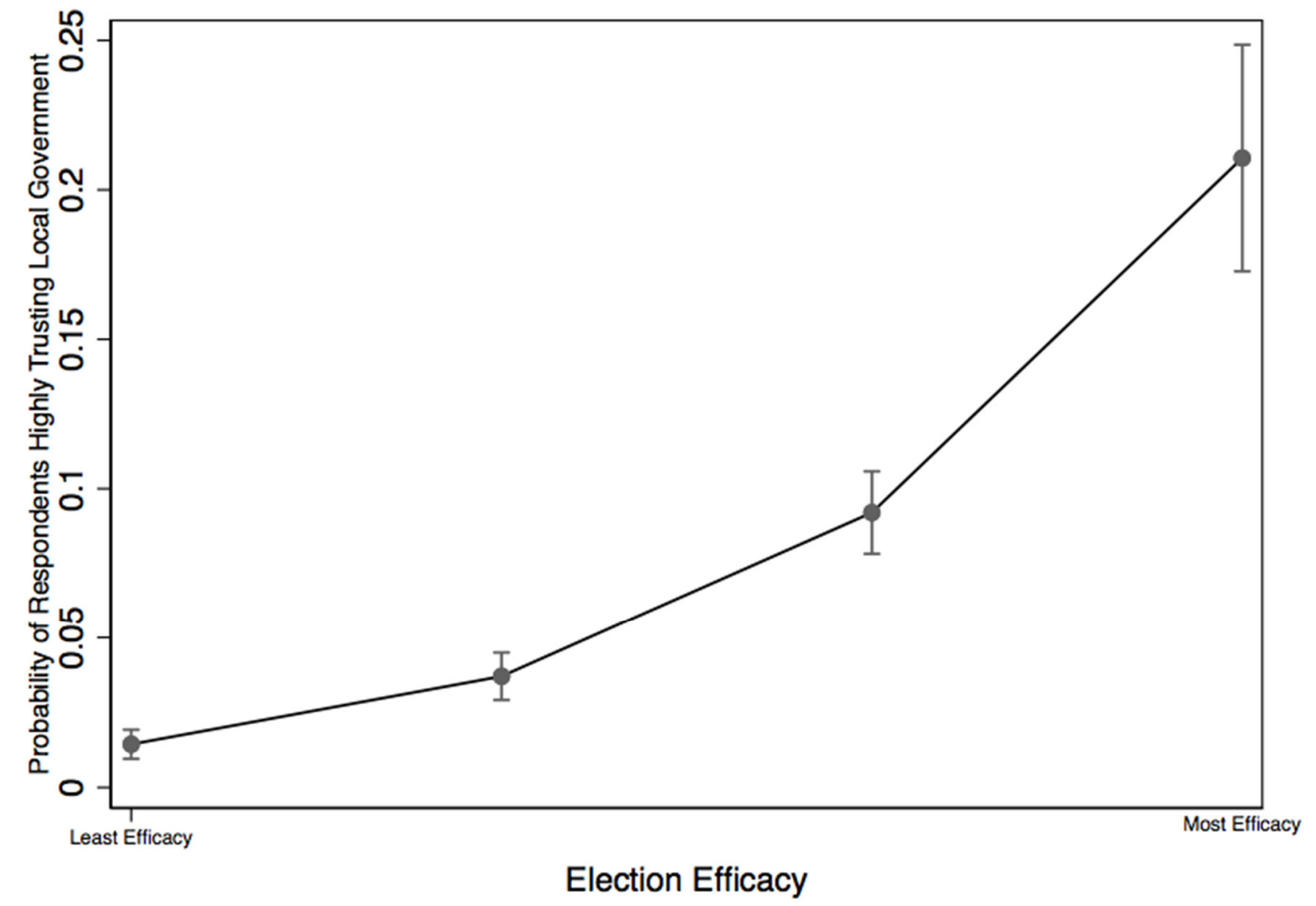

Figure 1. Predicted probability of respondents highly trusting the local Chinese government by election efficacy. Source: Asian Barometer Survey (2014), data used by permission, figure drawn by the author.

Two control variables figure prominently in contributing explanatory power in the model: national economy and social status. Both variables had a positive and statistically significant impact upon the dependent variable, even after controlling for the remaining idiosyncratic control variables. This finding suggests that, in deciding whether to trust the local government, respondents' read of national economy and their social status matter. This lends evidence to our previous assumption of this causal relationship 
that a positive outlook of the national economy projects confidence to individuals regarding their future lives and therefore positively affects popular trust toward the local government.

Similarly, a better social status places respondents at the higher end of the social ladder, securing respondents much better and more accessible political, social and networking resources both in the good and bad times of the economy. This positiveness translates into higher trust of their local governments. Alternatively, respondents with more prestigious social status are more likely to highly trust their local governments maybe simply because they have formed personal alliance networks with the local government apparatus. These local corporatist associations and networks expose the villagers to the sphere of the haves, versus the have-nots, in connection with the local governments.

\section{Discussion and Conclusions}

Rural elections in China, by any measure, fall short of the strict standards of democratic elections that characterize the western democracies. Yet, we held in this essay that, despite the flaws, rural elections in China still serve the interest of the CCP in instituting more transparent and efficient local governance. If without this institutional arrangement of democratic elections, it would take tremendous political and financial resources to achieve better local governance. On a systemic level, rural elections free up the resources that the CCP pumps down to localities by assuming control and command over local cadres. Elections would come across to the CCP central government as an advantage in disciplining local elites and bringing them in line with pragmatic local affairs.

Upon future empirical confirmation of the theoretical argument laid out in this essay, as we have conducted in this study, rural elections sit poised to impose discipline and accountability on local government officials. In other words, the empowered peasants have the potential to exert considerable amount of influence upon the authority of one or two levels higher, namely the township or county level government. Opening up local elections help the Chinese government assume better command over local authorities. The central government may attempt to find that equilibrium point where democratic elections are not too overwhelming for the CCP to lose control while these elections still serve to better local governance and bring about systematic cohesion within the Chinese regime. The central government should seek to further open up local elections up to the equilibrium point where popular bottom-up pressure increases the accountability of the local government but does not spill into wider scales of unrests. Managing to keep the fine balance between democratic self-governance from blow and authoritarian control from above would benefit the whole CCP regime.

Author Contributions: Conceptualization, J.X. and F.W.; methodology, J.X.; software, J.X.; validation, J.X.; formal analysis, J.X.; investigation, J.X. and F.W.; resources, J.X. and F.W.; data curation, J.X.; writing-original draft preparation, J.X.; writing - review and editing, J.X.; visualization, J.X.; supervision, J.X.; project administration, J.X. and F.W.; funding acquisition, F.W.

Funding: This research was funded by [Overseas Chinese and Implementation of China's BRI Project, A Key Section of the Humanities and Social Sciences Key Research Bases under the Ministry of Education, 2016] grant number [16JJD810006].

Conflicts of Interest: This project declares no conflict of interest.

\section{References}

1. Xi, J.; Marketing the Party: Official Inspections in China. J. Books Ideas. Available online: http://www. booksandideas.net/Marketing-the-Party.html (accessed on 10 November 2016).

2. Xi, J. Chinese Government Village Inspections: Where Does the King Show Up? Asian Surv. 2017, 57, 450-474. [CrossRef]

3. Xi, J. Sustainable Legitimacy: Chinese Government Inspections and Public Approval of Village Leadership. Sustainability 2018, 10, 1975. [CrossRef]

4. Knight, J. Institutions and Social Conflict; Cambridge University Press: Cambridge, UK, 1992.

5. Huntington, S. Political Order in Changing Societies; Yale University Press: New Haven, CT, USA, 1968.

6. Milnor, A.J. Elections and Political Stability; Little, Brown and Company: Boston, MA, USA, 1969. 
7. Przeworshi, A. Democracy and the Market; Cambridge University Press: Cambridge, UK, 1991.

8. Flores, T.E.; Nooruddin, I. The Effect of Elections on Post-conflict Peace and Reconstruction. J. Politics 2012, 74, 558-570. [CrossRef]

9. Snyder, J. From Voting to Violence; W.W. Norton \& Company, Inc.: New York, NY, USA, 2000.

10. Li, L. Elections and Popular Resistance in Rural China. (Revised Version). China Inf. 2002, 16, 89-107.

11. Xia, M. Social capital and rural grassroots governance in China. J. Curr. Chin. Aff. 2011, 40, 135-163. [CrossRef]

12. Wang, S.; Yang, Y. Grassroots Democracy and Local Governance: Evidence from Rural China. World Dev. 2007, 35, 1635-1649. [CrossRef]

13. Li, S. Chinese Household Income Project; ICPSR21741-v1; Inter-University Consortium for Political and Social Research: Ann Arbor, MI, USA, 2002. [CrossRef]

14. Kelliher, D. The Chinese Debate Over Village Self-Government. China J. 1997, 63-68. [CrossRef]

15. Kennedy, J.J.; Shijiang, Y. Surveys and Learning about Village Elections and Rural China: An Analysis of a 2005 National Village Election Survey. In Politics and Markets in Rural China; Alpermann, B., Ed.; Routledge: London, UK, 2011; p. 213.

16. Hong, Z. Three disconnects' and China's rural election: A case study of Hailian Village. Communist PostCommunist Stud. 2006, 39, 25-37. [CrossRef]

17. O'Brien, K. Implementing Political Reform in China's Villages. Aust. J. Chin. Aff. 1994, 33-59. [CrossRef]

18. Shi, T. Voting and Nonvoting in China: Voting Behavior in Plebiscitary and Limited-Choice Elections. J. Politics 1999, 61, 1115-1139. [CrossRef]

19. McCormick, B.L. China's Leninist Parliament and Public Sphere: A Comparative Analysis. In China after Socialism: In the Footsteps of Eastern Europe or East Asia? McCormick, B.L., Unger, J., Eds.; M.E. Sharpe: Armonk, NY, USA, 1990.

20. Hillman, B. Factions and Spoils: Examining Political Behavior within the Local State in China. China J. 2010, 64, 1-18. [CrossRef]

21. Yao, Y. Village elections, accountability and income distribution in rural China. China World Econ. 2006, 14, 20-38. [CrossRef]

22. Luo, R.; Zhang, L.; Huang, J.; Rozelle, S. Elections, fiscal reform and public goods provision in rural China. J. Comp. Econ. 2007, 35, 583-611. [CrossRef]

23. Zhang, X.; Fan, S.; Zhang, L.; Huang, J. Local governance and public goods provision in rural China. J. Public Econ. 2004, 88, 2857-2871. [CrossRef]

24. Meng, X.; Zhang, L. Democratic Participation, fiscal reform and local governance: Empirical evidence on Chinese villages. China Econ. Rev. 2011, 22, 88-97. [CrossRef]

25. Wang, Z.; Dai, W. Women's Participation in Rural China's Self-Governance: Institutional, Socioeconomic, and Cultural Factors in a Jiangsu County. Governance 2013, 26, 91-118. [CrossRef]

26. Yang, Q.; Tang, W. Exploring the Sources of Institutional Trust in China: Culture, Mobilization, or Performace? Asian Politics Policy 2010, 415-436. [CrossRef]

27. Goodwin, J. State-centered Approaches to Social Revolutions: Strengths and Limitations of a Theoretical Tradition. In Theorizing Revolutions; Foran, J., Ed.; Routledge: London, UK, 1997.

28. Landry, P.F.; Davis, D.; Wang, S. Elections in rural China: Competition without parties. Comp. Political Stud. 2010, 43, 763-790. [CrossRef]

29. Oi, J.; Rozelle, S. Elections and Power: The Locus of Decision-Making in Chinese Villages. China Q. 2000, 162, 513-539. [CrossRef]

30. Kennedy, J.J. Supply and support for grassroots political reform in rural China. J. Chin. Political Sci. 2010, 15, 169-190. [CrossRef]

31. Wilking, J.R.; Zhang, G. Accepting the Bargain? An Experimental Study of Political Rights, Economic Development and Support for Government in Rural China. J. Chin. Political Sci. 2013, 18, 241-257. [CrossRef]

32. CGSS 2013. Chinese National Survey Data Archive. Available online: http://cnsda.ruc.edu.cn/ (accessed on 5 October 2019).

33. Chen, J.; Xu, Y. Authoritarian governance with public communication. In Proceedings of the Annual Conference of the Midwest Political Science Association, Chicago, IL, USA, 11-14 April 2014.

34. Zhu, Y. 'Performance Legitimacy' and China's Political Adaptation Strategy. J. Chin. Political Sci. 2011, 16, 123-140. [CrossRef] 
35. Wang, X. Mutual Empowerment of State and Peasantry: Grassroots Democracy in Rural China. World Dev. 1997, 25, 1431-1442. [CrossRef]

36. Chang, S.; Hess, S. The Diffusion of Contention in Contemporary China: An investigation of the 2014-15 wave of teacher strikes. Mod. Asian Stud. 2018, 52,1-22. [CrossRef]

37. Shi, T. Village Committee Elections in China: Institutionalist Tactics for Democracy. World Politics 1999, 51, 385-412. [CrossRef] article distributed under the terms and conditions of the Creative Commons Attribution (CC BY) license (http://creativecommons.org/licenses/by/4.0/). 